\title{
グリッドレス法によるボルツマン方程式解法の信頼性検証*
}

\author{
森西晃嗣*1

\section{Numerical Validation of Gridless Boltzmann Equation Solver} \\ Koji MORINISHI*2 \\ ${ }^{* 2}$ Department of Mechanical and System Engineering, Kyoto Institute of Technology,
Matsugasaki, Sakyo-ku, Kyoto-shi, Kyoto, 606-8585 Japan

\begin{abstract}
This paper describes a numerical solver of the Boltzmann equation which is originally developed for micro scale flow simulations. The convection terms are evaluated with an upwind gridless method, while the collision term is evaluated using a kinetic model collision term which correctly resembles the lower 13 moments of the Boltzmann equation. Validation of the solver is carried out for a supersonic flow over a circular cylinder at a free stream Mach number of 2.0 and several Knudsen numbers from 0.01 to 1.0 . The numerical results are compared with those of the direct simulation Monte Carlo (DSMC) method and those of the compressible Navier-Stokes equations with slip boundary conditions. The comparison indicates that the results of the present Boltzmann equation solver are in good agreement with those of the DSMC method for the whole range of Knudsen number considered and the predictions of the slip Navier-Stokes equations are adequate if the Knudsen number is less than 0.1 .
\end{abstract}

Key Words : Computational Fluid Dynamics, Rarefied Gas, Supersonic Flow, Gridless Method, Boltzmann Equation

\section{1. 序}

望

MEMS (Micro Electro Mechanical Systems) p NTBS (Nano Technology Base Systems) の開発に関 連して, マイクロスケールの流動現象に対する実用的 なシミュレーション技術の確立が求められている. 一 般に, 標準状態の空気の平均自由行程は約 $0.06 \mu \mathrm{m}$ と 見積もられており, 流れの代表長さが $10 \mu m$ 程度と成 ると固体塈境界での速度の滑りや温度の跳びの影響が 無視出来なくなり，粘着境界条件を用いたナビエ・ス トークス方程式によるシミュレーションの信頼性が失 われる.ささらに, 流れの代表長さが $1 \mu m$ 程度と成る と連続体理論に基づくナビエ・ストークス方程式自体 の正当性が失われる.

従来, 流れの代表長さと平均自由行程が同程度とな る中間流領域の流動現象は, 希薄気体力学の分野で取 り扱われ，シミュレーションにはモンテカルロ直接シ ミュレーション (DSMC) 法 ${ }^{(1)}$ が標準解法として広く 用いられてきた. しかしながら，希薄気体力学が主に 対象としてきた超音速や極超音速の流れとは異なり, マイクロスケール流れは一般に低速流れであるため,

* 原稿受付 2005 年 4 月 6 日.

*1 正員, 京都工芸瀻維大学工芸学部 (-606-8585 京都市左京 区松ヶ崎御所海道町).

E-mail : morinisi@ kit.ac.jp
必然的に分散誤差を伴なう DSMC 法は，有意義なシ ミュレーション結果を得るためには莫大なサンプル数 が必要となり，現在のコンピュータの演算性能では実 用的な問題への適用は不可能と考えられている ${ }^{(2)(3)}$.

一方, ボルツマン方程式の複雑な街突項をモデル化 し, 移流項の評価には計算流体力学的手法を用いる希 薄気体流れのシミュレーション方法 ${ }^{(4)(5)}$ は, 極超音速 流れへの適用は経済的で無いが(6)，低速のマイクロス ケール流れに対しては, 分散俱差を伴なわ無いために DSMC 法よりはるかに経済的で, 実用的なシミュレー ション手法と成ることが期待出来る(7). しかしながら， ボルツマン方程式の衝突項をモテル化しているため, 希薄化による非平衡な流れに対して得られる解の信頼 性には疑問が残る。

そこで, 本研究では, MEMS などの精䋗な形状に対 しても柔軟な対応が期待できるグリッドレス法 ${ }^{(8)}(9)$ と 最初の有意な 13 モーメント（罂量, 運動量, 応カテン ソル，および, 熱流束）まで近似する衝突項モデル ${ }^{(10)}$ を、それぞれ，移流項と街突項の評価に用いたボルツ マン方程式解法を新たに構筑し, 中間流領域の微小円 柱周りの流れのシミュレーションを行い, 標準解法で ある DSMC 法の結果と直接比較することにより，そ の信頼性の検証を行う. 実際のマイクロスケール流れ のマッハ数は $10^{-4} \sim 10^{-1}$ 程度であるが, DSMC 法を 
用いてその様な低速流れに対して信頼出来る結果を得 るのは困難なため, ここでは, 一様流マッ八数は 2.0 とする. また，比較のため，固体表面で速度の滑りと 温度の跳びを付加した圧縮性ナビエ・ストークス方程 式に基づくシミュレーションも行う.

\section{2. ボルツマン方程式}

気体分子の運動を記述するボルツマン方程式は，外 力項を無視すると，一般に，次のように書かれる.

$$
\frac{\partial f}{\partial t}+\mathbf{c} \cdot \frac{\partial f}{\partial \mathbf{x}}=\iint\left(f^{*} f_{1}^{*}-f f_{1}\right) c_{r} \sigma d \Omega d \mathbf{c}_{1}
$$

ここで, $f$ は速度分布関数, $\mathrm{c}$ は分子速度, $c_{r}$ は街突 する分子間の相対速度 $\mathrm{c}_{r}$ の絶対值， $\sigma d \Omega$ は微分街突 断面積である.

ボルツマン方程式の右辺衝突項は, 複雑な 5 重積分 となるため, その䈔密な評価には多大な演算量が必要 になる.ここでは，質量，運動量，応カテンソル，お よび，熱流束など最初の有意な 13 モーメントまでを 近似した衝突項モデル ${ }^{(10)}$ を用いたボルツマン方程式を 基礶方程式とする. それは，無次元変数表示で以下の ように示される.

$$
\frac{\partial f}{\partial t}+\mathbf{c} \cdot \frac{\partial f}{\partial \mathbf{x}}=v\left(f_{o}-f\right)
$$

ここで, 分布関数 $f_{o}$ は, 平衡分布関数 $f_{e}$,

$$
f_{e}=\frac{n}{(\pi T)^{3 / 2}} \exp \left(-\frac{\mathbf{C}^{2}}{T}\right)
$$

を用いて，次式で与えられる。

$$
f_{o}=f_{e}\left[1+\frac{2}{5 p T}(1-\operatorname{Pr}) \mathbf{C} \cdot \mathbf{q}\left(\frac{2 \mathbf{C}^{2}}{T}\right)\right]
$$

ただし, Prはプラントル数である.

流れの巨視的物理量である数密度 $n$, 平均速度 $\mathbf{u}$, 温 度 $T$, および, 熱流束 $q$ は, 分布関数 $f$ に対するモー メントとして, 次のように求めることが出来る.

$$
\begin{gathered}
n=\int f d \mathbf{c} \\
n \mathbf{u}=\int \mathbf{c} f d \mathbf{c} \\
\frac{3}{2} n T=\int \mathbf{C}^{2} f d \mathbf{c} \\
\mathbf{q}=\int \mathbf{C C}^{2} f d \mathbf{c}
\end{gathered}
$$

また，熱速度 $\mathbf{C}$ は，分子速度 $\mathbf{c}$ と平均速度 $\mathbf{u}$ により， 次のように定義される.

$$
\mathbf{C}=\mathbf{c}-\mathbf{u}
$$

街突頻度数 vは, 一様流の基準クヌッセン数 $K n$ を 用いて，次のように表される.

$$
v=\frac{8 n T^{s}}{5 \sqrt{\pi} K n}
$$

ここで, $s$ は，分子モデルにより決まる指数で，例え ば, 剛体球分子では 0.5 , マクスウェル分子では 0.0 と なる. ただし, 速度の無次元化に用いる代表流速は,

$$
C_{\infty}=\sqrt{2 R T_{\infty}}
$$

で与えられ，一様流（基盜状態）の分子の平均自由行 程 $l_{\infty}$ は, 次式で与えられるとした.

$$
l_{\infty}=\frac{16 \mu_{\infty}}{5 \sqrt{\pi} m n_{\infty} C_{\infty}}
$$

ここに, $R$ は気体定数, $\mu$ は粘性係数, $m$ は分子 1 個 の質量である. なお，以下の表記では，Kn は常に一 様流の基準クヌッセン数を示す.

\section{3. 樎退分布関数}

2 次元流れを取り扱う場合でも，個々の気体分子は 3 次元運動をするため, 速度分布関数 $f$ は, 時間 $t$ を除いても， 2 次元の位相 $\mathrm{x}(x, y)$ と 3 次元の分子速 度 $\mathrm{c}\left(c_{x}, c_{y}, c_{z}\right)$ の合計 5 次元空間の関数となり, そのシ ミュレーションには多くの演算量と記憶容量が必要と なる. そこで, 2 次元流れの計算に際しては, 演算量 と記憶容量を節約するために, 次式で定義される縮退 分布関数 $g$ と $h$ を導入する.

$$
\begin{gathered}
g=\int f d c_{z} \\
h=\int c_{z}^{2} f d c_{z}
\end{gathered}
$$

ボルツマン方程式 (2) も同様に積分すると，縮退分布 関数 $g$ と $h$ に対するボルツマン方程式が次式のように 得られる.

$$
\begin{aligned}
& \frac{\partial g}{\partial t}+\mathrm{c} \cdot \frac{\partial g}{\partial \mathbf{x}}=v\left(g_{o}-g\right) \\
& \frac{\partial h}{\partial t}+\mathrm{c} \cdot \frac{\partial h}{\partial \mathbf{x}}=\mathrm{v}\left(h_{o}-h\right)
\end{aligned}
$$

ただし，ここでの分子速度 $\mathbf{c}$ は, 2 次元分子速度 $\mathbf{c}\left(c_{x}, c_{y}\right)$ である. また, 分布関数 $g_{o}$ と $h_{o}$ は, 式 (4) の分布関数 $f_{o}$ に式 (10)の䖽分を適用することにより, それぞれ, 求められる.

さらに, 2 次元流れの平均速度を $\mathbf{u}(u, v)$ とすると， 熱速度 $\mathbf{C}$ は,

$$
\mathbf{C}=\left(c_{x}-u, c_{y}-v\right)
$$


のように定義され，式 (5) で示されるモーメントも， 縮退分布関数 $g$ と $h$ に対するモーメントとして, 次式 のように与えられる.

$$
\begin{gathered}
n=\int g d \mathbf{c} \\
n \mathbf{u}=\int \mathbf{c} g d \mathbf{c} \\
\frac{3}{2} n T=\int\left(\mathbf{C}^{2} g+h\right) d \mathbf{c} \\
\mathbf{q}=\int \mathbf{C}\left(\mathbf{C}^{2} g+h\right) d \mathbf{c}
\end{gathered}
$$

\section{4. 数 值計算 法}

縮退分布関数 $g$ と $h$ に対するボルツマン方程式 (11) の解法は, 2 次元の物理空間と 2 次元の分子速度空間 を合わせた 4 次元空間を離散化して行う. 移流項の離 散化には，最終目標である精䋨なマイクロ機器への応 用を考虑して，柔軟性の高いグリッドレス法 ${ }^{(8)}{ }^{(9)}$ を用 いる. グリッドレス法では, 計算領域内に分布させた 任意の点 $i$ で任意の関数 $f$ の勾配を, まわりの点群 $(ク$ ラウド : $C(i))$ での関数值を用いて, 次のように評価 する.

$$
\left.\frac{\partial f}{\partial \mathbf{x}}\right|_{i}=\sum_{k \subset C(i)} \mathbf{a}_{i k} f_{i k}
$$

ここで, 添え字 $k$ はクラウド $C(i)$ に含まれる点を示 し, $f_{i k}$ は点 $i$ と点 $k$ の中点での関数の值である.

グリッドレス法を式 (11) の空間微分項に適用する と, 次式のようになる.

$$
\begin{aligned}
\left.\mathbf{c} \cdot \frac{\partial \mathbf{q}}{\partial \mathbf{x}}\right|_{i} & =\sum_{k \subset C(i)}\left(\mathbf{a}_{i k} \cdot \mathbf{c}\right) \mathbf{q}_{i k} \\
& =\sum_{k \subset C(i)} \mathbf{F}_{i k}
\end{aligned}
$$

ここで, q は,

$$
\mathbf{q}=\left(\begin{array}{l}
g \\
h
\end{array}\right)
$$

であり,また, $\mathbf{F}_{i k}$ は,

$$
A_{i k}=\mathbf{a}_{i k} \cdot \mathbf{c}
$$

として, 次式により求める.

$$
\mathbf{F}_{i k}=\frac{1}{2}\left\{A_{i k}\left(\mathbf{q}_{i k}^{r}+\mathbf{q}_{i k}^{l}\right)-\left|A_{i k}\right|\left(\mathbf{q}_{i k}^{r}-\mathbf{q}_{i k}^{l}\right)\right\}
$$

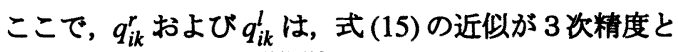
なるように補間する ${ }^{(11)(12)}$.
時間積分法には LU-SGS 法 ${ }^{(13)}$ を採用する. 式 (11) に陰的オイラー法を適用すると，次式のようになる.

$$
\begin{array}{r}
\left(\frac{1}{\Delta t_{i}} \mathbf{I}+\sum_{k \subset C(i)} A_{i k}^{+}\right) \Delta \mathbf{q}_{i}+\sum_{k \subset C(i)} A_{i k}^{-} \Delta \mathbf{q}_{k} \\
=R H S_{i}
\end{array}
$$

ここで, $R H S_{i}$ は, 式(11)の時間微分項以外の項を示 し, $A^{ \pm}$は,

$$
A^{ \pm}=\frac{1}{2}(A \pm|A|)
$$

である.

この線形連立方程式の解法は, クラウド $C(i)$ を $L(i)$ とU(i)に分割して, 次式のように行う.

$$
\begin{gathered}
\Delta q_{i}^{*}=D_{i}^{-1}\left(R H S_{i}-\sum_{k \subset L(i)} A_{i k}^{-} \Delta \mathbf{q}_{k}\right) \\
\Delta q_{i}=\Delta q_{i}^{*}-D_{i}^{-1} \sum_{k \subset U(i)} A_{i k}^{-} \Delta \mathbf{q}_{k}
\end{gathered}
$$

ここで， $D_{i}$ は，次のようなスカラー量である.

$$
D_{i}=\left(\frac{1}{\Delta t_{i}}+\frac{1}{2} \sum_{k \subset C(i)}\left|A_{i k}\right|\right)
$$

最後に, 流れの巨視的物理量は, 式(13)に対して, 例えば，

$$
n=\iint g d c_{x} d c_{y}=\sum \sum w g
$$

のような数值積分則を用いて求める. ここに, $w$ は数 値積分則の重み係数である.

\section{5. 就算条件}

MEMS などのマイクロスケール流れは低速である が, 低速流れのシミュレーションが困難な DSMC 法 との比較を容易にするために，ここでは，2次元円柱 を過ぎる一様流マッ八数 $M_{\infty}=2.0$ の流れ場を取り上 げ, グリッドレス法によるボルツマン解法の信頼性検 証を行う. 一様流の基準クヌッセン数 $K n$ は, 代表長 さを円柱直径に取り, $0.01 \sim 1.0$ の篹囲とした. 比較 のため, DSMC 解法 ${ }^{(1)(2)}$, および, 円柱表面で一次の 滑り境界条件を与えた圧縮性ナビエ・ストークス方程 式のグリッドレス解法 ${ }^{(8)(9)}$ も行った.

分子の衙突モデルは剛体球分子を想定し, DSMC 解 法では最大衝突数法を用いた. ナビエ・ストークス方 程式の粘性係数 $\mu$ は,

$$
\mu \propto T^{0.5}
$$

に従い,レイノルズ数 Reは, 次式で与えられるとした.

$$
R e=\sqrt{\frac{\pi \gamma}{2}} \frac{M_{\infty}}{K n}
$$




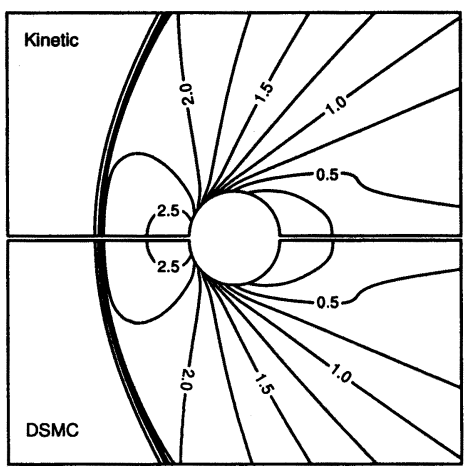

Fig. 1 Comparison of density contors between kinetic and DSMC results at $K n=0.01$.

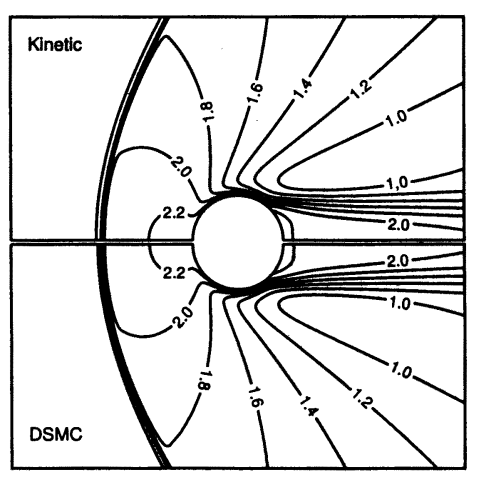

Fig. 2 Comparison of temperature contors between kinetic and DSMC results at $K n=0.01$.

ここで, $\gamma$ は比熱比である. また, 円柱表面温度 $T_{w}$ に は, 次式で求まる全温度を与えた。

$$
T_{o}=T_{\infty}\left(1+\frac{\gamma-1}{2} M_{\infty}^{2}\right)
$$

物理空間の計算領域は，円柱を中心に外側境界まで の距離を円柱直径の約 11 倍とした. ボルツマン解法 とナビェ・ストークス解法の計算点と DSMC 解法の 計算セルは同じ計算格子より定めた（但し，物理量の 定義点は, 前者は格子交点, 後者はセル中心である）. 計算格子は, 円周方向に等間隔の構造格子で, 各セル 中心での円周方向の長さと半径方向の長さが等しくな るよう, 解析的に作成した. 格子点数は, 円柱近傍で の格子間隔がその場所の局所平均自由行程より小さく なるように, 流れのクヌッセン数に応じて定め, さら に格子点数を変えた数值実験によりその妥当性（抵抗 係数の差異が最大で $0.1 \%$ 程度）を確認した.

また, ボルツマン解法における分子速度空間の格子 点数は, 流れのクヌッセン数によらず, 一方向当たり

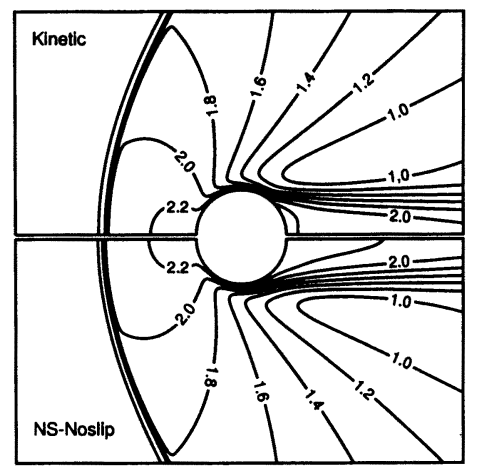

Fig. 3 Temperature contors obtained with kinetic and nonslip Navier-Stokes results at $K n=0.01$.

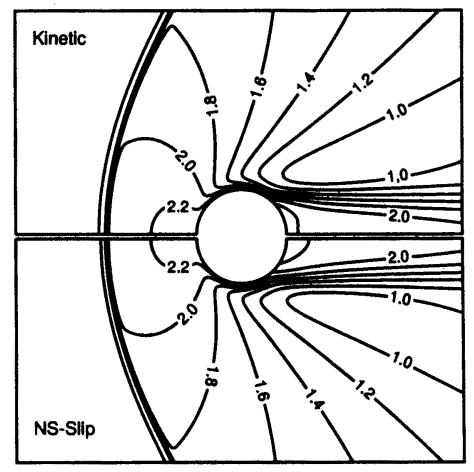

Fig. 4 Temperature contors obtained with kinetic and slip Navier-Stokes results at $K n=0.01$.

28 点（ $\Delta c=0.5 ）$ とした場合と 56 点 $(\Delta c=0.25)$ と した塌合とで，抵抗俰数の差異が最大でも $0.05 \%$ 程度 であることを確認した。これに対して DSMC 解法で は，基準状㸃で 1 セル当たりに平均 100 個のサンプル 分子が入るようにした.

境界条件は，ボルツマン解法と DSMC 解法では，円 柱表面では拡散反射条件を与え，遠方境界では，流入 する分子は平衡分布で与え，流出する分子は自由流出 とした.これに対して，ナビェ・ストークス解法では， 遠方境界は，超音速の流入・流出を仮定し，流入境界 は一様流で固定し，流出境界は自由流出とした．また， 円柱表面では，粘着条件（ $u_{w}=0, T_{w}=T_{0} ）$ に対する 修正として，次式の一次精度滑り境界条件を与えた。

$$
\begin{gathered}
u_{s}-u_{w}=K n \frac{\mu}{\rho \sqrt{T_{w}}} \frac{\partial u}{\partial n}+\frac{3}{4} \sqrt{\frac{\pi}{2}} K n \frac{\mu}{\rho T_{w}} \frac{\partial T}{\partial s} \\
T_{s}-T_{w}=\frac{2 \gamma}{\gamma+1} \frac{K n}{\operatorname{Pr}} \frac{\mu}{\rho \sqrt{T_{w}}} \frac{\partial T}{\partial n}
\end{gathered}
$$

ここで, $s$ と $n$ は接線方向と法線方向を示し, $u_{s}$ と $T_{s}$ は滑り境界条件として与える接線流速と温度を示す。 


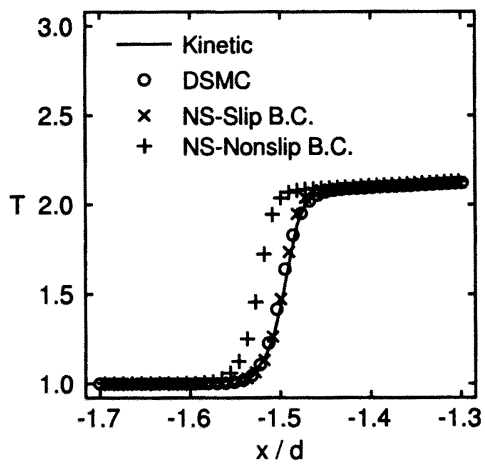

Fig. 5 Comparison of temperature distribution along front stagnation line at $K n=0.01$.

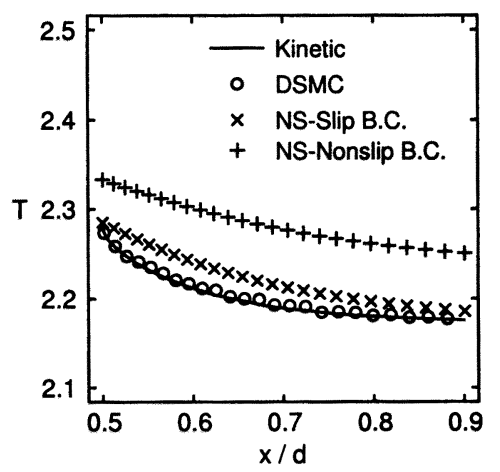

Fig. 6 Comparison of temperature distribution along rear stagnation line at $K n=0.01$.

\section{6. 計 算 結 果}

6.1 $K n=0.01$ の流れ 最初に, クヌッセン数 $K n=0.01$ の流れに対するシミュレーション結果の比 較を示す. 図 1 と図 2 は, ボルツマン解法およびDSMC 解法により得られた, それぞれ, 密度分布と温度分布の 比較を示す. それぞれの解法による流れのシミュレー ションは, $1024 \times 513$ の物理空間格子を用いて行った が, ボルツマン (Kinetic) 解法については上半分領域 の結果を, DSMC 解法については下半分領域の結果 を，それぞれ，表示している．両図より，街整波や後 流の領域を含めた全領域において，両者のシミュレー ション結果はよく一致していることが確認出来る.

図 3 は, 同じ流れに対して得られたボルツマン解 法の結果と固体壁境界で粘着条件を用いたナビエ・ス トークス解法の結果の比較を示す. 粘着条件を用いた ナビエ・ストークス解法の結果は, 街慗波が少し前方 で捕らえられ, また, 後流の温度分布も少し異なって いることが分かる.

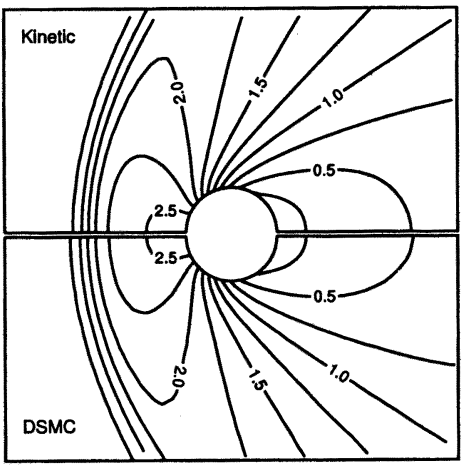

Fig. 7 Comparison of density contors between kinetic and DSMC results at $K n=0.1$.

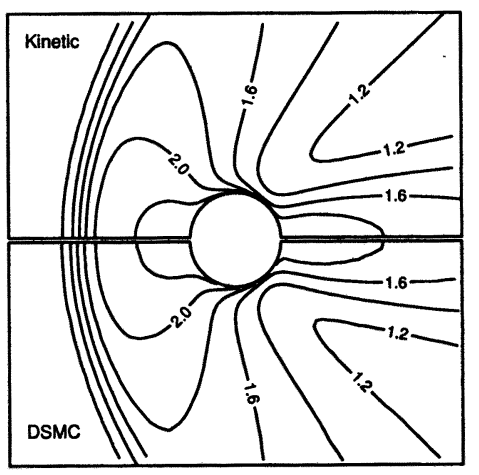

Fig. 8 Comparison of temperature contors between kinetic and DSMC results at $K n=0.1$.

次に，固体壁境界で滑り条件を用いたナビエ・ストー クス方程式の結果を図 4 に示す.一般に, 連続体（粘 着条件を用いたナビエ・ストークス方程式）の仮定が 成り立つクヌッセン数の範囲は $K \boldsymbol{n}<0.01$ で, これ以 上のクヌッセン数の流れでは, 固体表面での速度の滑 りや温度の跳びが無視出来なくなると考えられている. 滑り条件を用いたナビエ・ストークス解法の結果は, 街整波の位目や後流部分の分布が，粘着条件を用いた 解法の結果（図3）と比較して，相対的により良くボ ルツマン解法の結果と一致している.

図 5 および図 6 は，それぞれ，前方および後方中 心線上で 4 解法により予测される温度分布の比較を示 す.これらの図においても，ボルツマン解法と DSMC 解法の結果は非常に良く一致していることが確認出来 る. また，粘着条件を用いたナビエ・ストークス方程 式の結果は, 得繋波を $2 \%$ 程度前方で捕らえ, 後流の 温度分布も $5 \%$ 程度高く成っているのに対して, 滑り 条件の結果は, 街繋波の位目をほぼ正確に予測してお 


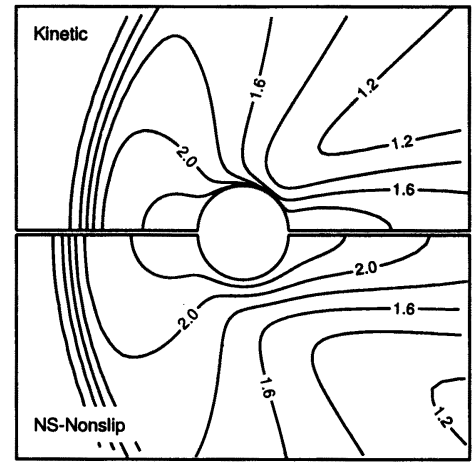

Fig. 9 Temperature contors obtained with kinetic and non-slip Navier-Stokes results at $K n=0.1$.

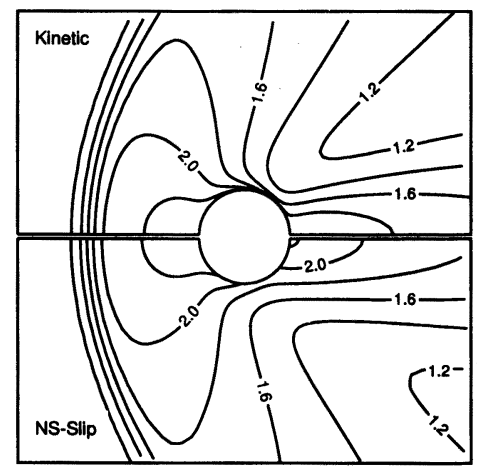

Fig. 10 Temperature contors obtained with kinetic and slip Navier-Stokes results at $K n=0.1$.

り, 後流の温度分布もボルツマン解法や DSMC 解法 の結果と比較的良く一致していることが確認出来る.

6.2 $K n=0.1$ の流れ 次に, 滑り条件を用いた ナビエ・ストークス方程式の適用限界とされる, クヌッ セン数 $K n=0.1$ の流れを取り上げる. 物理空間格子 には, $128 \times 65$ 点を用いた. 図 7 と図 8 は, ボルツマ ン解法およびDSMC 解法により得られた，それぞれ， 密度分布と温度分布の比較を示す．希薄化の影警が無 視出来ないクヌッセン数の流れにおいても，街慗波や 後流部分を含めた全領域において，両者の結果は良く 一致していることが確認出来る.

図9は，同じ流れに対して得られたボルツマン解法 と粘着条件を用いたナビエ・ストークス解法により得 られた温度分布の比較を示す. クヌッセン数が 0.1 ま で高くなると，粘着条件を用いたナビエ・ストークス 解法の結果は，街慗波を明らかに前方で捕らえ，後流 の分布も大きく異なっていることが分かる. 一方，図

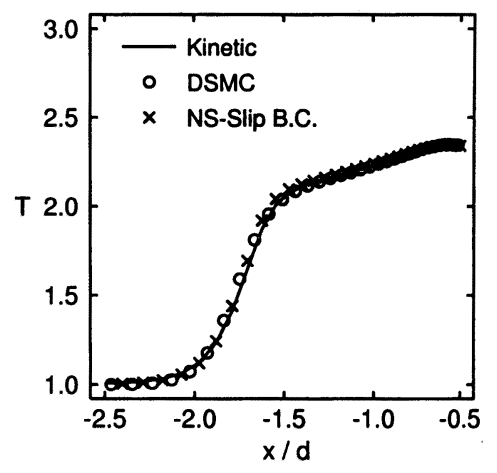

Fig. 11 Comparison of temperature distribution along front stagnation line at $K n=0.1$.

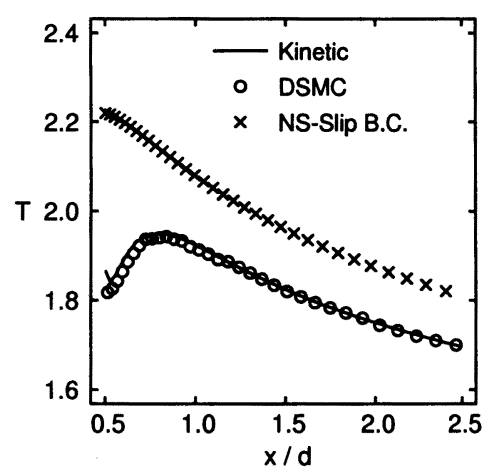

Fig. 12 Comparison of temperature distribution along rear stagnation line at $K n=0.1$.

10 に示す，滑り条件を用いたナビエ・ストークス解法 により得られた温度分布は，物体より前方の領域では 街波の位固を含めてボルツマン解法の結果と良く一 致しているが, 後流部分ではやはり分布が異なること が確認出来る.

図 11 および図 12 は，それぞれ，前方および後方 中心線上で 3 解法により予測される温度分布の比較を 示す.ここでは，粘着条件を用いたナビエ・ストーク ス解法の結果は, 他の解法の結果とは明らかに異なる ので, 省略している.これらの図においても，ボルツ マン解法と DSMC 解法の結果は全般的に非常に良く 一致しているが，滑り条件を用いたナビエ・ストーク ス解法の結果は, 前方中心線上ではボルツマン解法や DSMC 解法の結果と良く一致しているが，後方中心線 上での值は他の 2 解法の值より最大で $20 \%$ 程度高く 成っていることが確認できる. この理由としては, 密 度が一様流（基準状態）の值よりかなり低い後流部分 


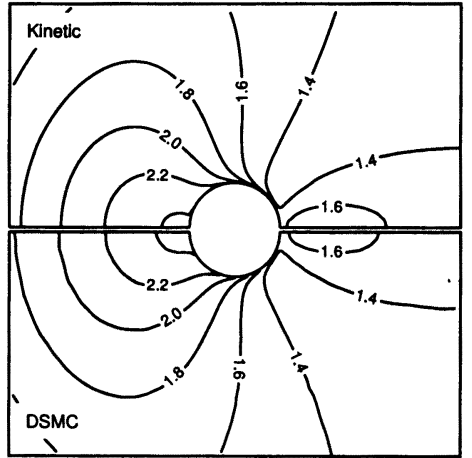

Fig. 13 Comparison of temperature contors between kinetic and DSMC results at $K n=1.0$.

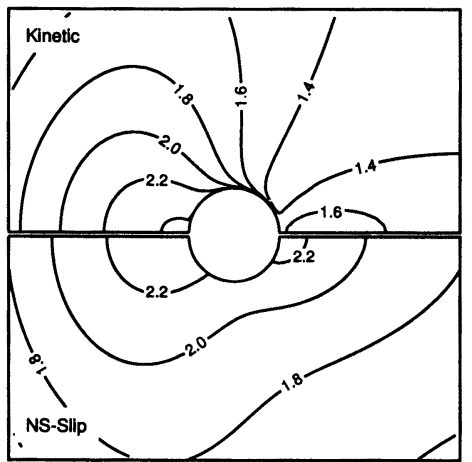

Fig. 14 Temperature contors obtained with kinetic and slip Navier-Stokes results at $K n=1.0$.

では，希薄化のため局所クヌッセン数が 0.1 よりかな り大きく成り，滑り条件を用いたナビェ・ストークス 方程式の適用限界を逸脱しているためと考えられる.

\section{3 $K n=1.0$ の流れ より希薄化の影険が影著} となるクヌッセン数 $K n=1.0$ の流れに対して得られ た結果の比較を, 図 13 から図 16 示す. 図 13 は, ボ ルツマン解法と DSMC 解法により得られた，温度分 布の比較を示す．また，図 14 は，ボルツマン解法と すべり条件を用いたナビエ・ストークス解法により得 られた，温度分布の比較を示す．さらに，図 15 およ び図 16 は，それぞれ，前方および後方中心線上で 3 解法により予測された密度分布の比較を示す.

クヌッセン数 $K n=1.0$ の場合でも，ボルッマン解 法と DSMC 解法により得られた結果は，密度分布に おいても温度分布においても，全体的に良く一致して いることが確認出来る．これに対して，すべり条件を

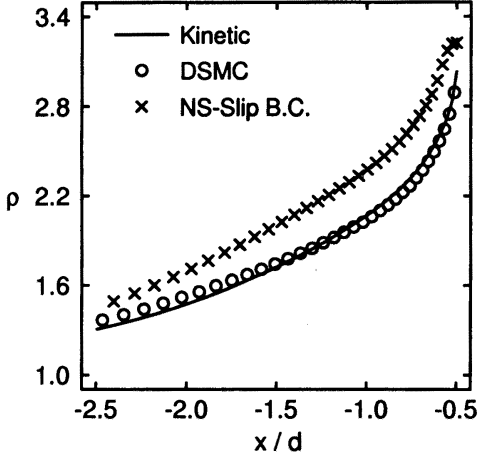

Fig. 15 Comparison of density distribution along front stagnation line at $K n=1.0$.

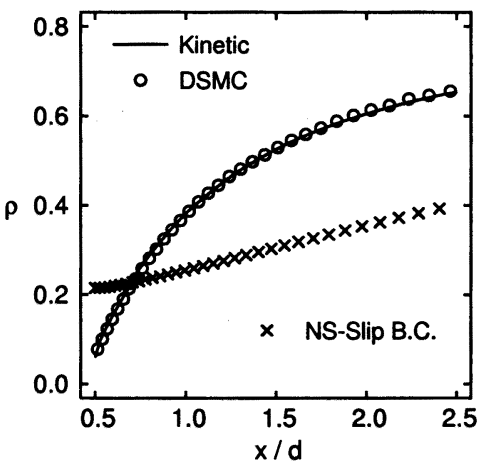

Fig. 16 Comparison of density distribution along rear stagnation line at $K n=1.0$.

用いたナビエ・ストークス解法の結果は，一般に，ナ ビエ・ストークス方程式が適用可能な範囲が, 固体壁 境界で滑り条件を導入しても， $K n \leq 0.1$ と言われてい るため, あまり期待出来ないが, 実際にボルツマン解 法により得られた結果と比較すると, 後流部分だけで なく上流部分においても, 分布の様子や值がかなり異 なっていることが確認できる.

6.4 抵抗係数の比较 最後に, クヌッセン数が $0.01 \leq K n \leq 1.0$ の範囲に対して，ボルツマン解法， DSMC 解法，および，滑り条件を用いたナビェ・ス トークス解法により得られた抵抗係数の比較を図 17 に示す. 比較のため Maslach と Schaaf ${ }^{(14)}$ の実験デー タも示す. ボルツマン解法と DSMC 法により予測さ れる抵抗係数は, 最大でも $1 \%$ 程度の差異しか無く, 良く一致している，また，滑り条件を用いたナビェ・ ストークス解法により予測される抵抗係数は, ボルツ マン解法の抵抗係数と比較すると，大きなクヌッセン 


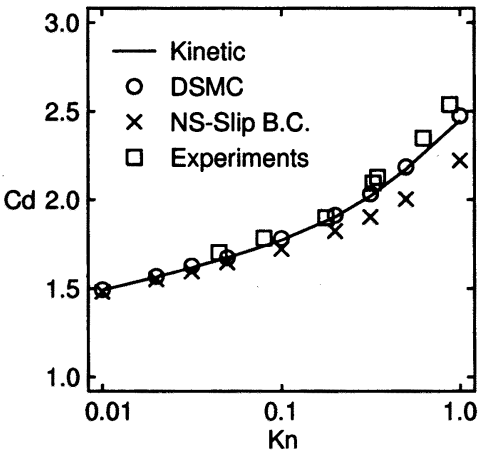

Fig. 17 Comparison of drag coefficients as a function of Knudsen number.

数に対しては最大で $9 \%$ 程度外れているが, $K n<0.1$ の籁囲では $1 \%$ 程度の差異で良く一致している.

異なる手法間での計算時間の比較は, 流れ場の条件 や計算条件（収束判定基準やサンプル数）に大きく依 存するため, 正確に行うことは難しいが, 今回行った 一様流マッハ数 2.0, クヌッセン数 0.1 の流れに対し ては, ボルツマン解法と DSMC 解法の計算時間はお よそ同じであった. したがって，一様流マッハ数が小 さくなるにつれて DSMC 解法の計算時間が飛羅的に 増加することを考虑すると，マッハ数が $10^{-4} \sim 10^{-1}$ 程度となるマイクロスケール流れに対してはボルツマ ン解法が圧倒的に優位となることが想定される.ただ し，ナビエ・ストークス解法と比較するとボルツマン 解法は一桁多くの計算時間を必要とするため, 流れの マッハ数が小さく希薄化に伴なう非平衡性が弱い流れ に対しては，滑り条件を用いたナビエ・ストークス解 法の利用も経済的と言える.

\section{7. 結 謚}

マイクロスケール流れのシミュレーション手法とし て, 複雑な衙突項をモデル化したボルツマン方程式に グリッドレス法を適用した解法を棈築し，微小円柱を 過ぎる一様流マッハ数 2.0 の流れのシミュレーション を行い, DSMC 法の結果と比較することにより，信頼 性の検証を行ったところ，次のような結論が得られた.

（1）ボルツマン解法と DSMC 解法により予測された 流れ場の密度分布や温度分布は，広いクヌッセン 数の範囲に対して，非常に良く一致した.

（2）固体壁境界で滑り条件を用いたナビエ・ストーク ス方程式により $K n<0.1$ の範囲で予测された密 度分布や温度分布は，希薄化が影著な後流部分に おいては多少違いが見られたが，前方部分に対し
ては衝慗波の位嘈も含めて, ボルツマン解法の結 果と比較的良く一致した.

（3）ボルツマン解法と DSMC 解法により予測された 抵抗係数は，広いクヌッセン数の篹囲に対して互 いに良く一致し，Kn<0.1 では固体壁境界で滑り 条件を用いたナビエ・ストークス方程式により予 測された抵抗係数とも良く一致した.

本研究の一部は, 科学研究補助金 (15560140) を得 て行なった.ここに記して謝意を表す.

\section{文献}

(1) Bird, G.A., Molecular Gas Dynamics and the Direct Simulation of Gas Flows, Oxford University Press (1994).

(2) Oran, E.S., Oh, C.K., and Cybyk, B.Z., Direct Simulation Monte Carlo: Recent Advances and Applications, Annual Review of Fluid Mechanics, 30 (1998), 403-442.

(3) Fan, J., Boyd, I.D., and Cai, C.P., Computation of Rarefied Gas Flows Around a NACA0012 Airfoil, AIAA Journal, 39-4 (2001), 618-625.

(4) Morinishi, K. and Oguchi, H., A Computational Method and Its Application to Analyses of Rarefied Gas Flows, Rarefied Gas Dynamics, University of Tokyo Press, 1 (1984), 149-158.

(5) Oguchi, H., Morinishi, K., and Satofuka, N., TimeDependent Approach to Kinetic Analyses of Twodimensional Rarefied Gas Flows, Rarefied Gas Dynamics, Plenum Publishing Corporation, 1 (1985), 293-302.

(6) Satofuka, N., Morinishi, K., and Oishi, T., Numerical Solution of the Kinetic Model Equations for Hypersonic Flows, Computational Mechanics, 11-5/6 (1993), 452464.

(7) Kamitsuji, K., Morinishi, K., and Satofuka, N., Numerical Simulation of Micro-Channel Flows Using Kinetic Model Equation, Transactions of the Japan Society of Mechanical Engineers, B 70 (2004), 2246-2251.

(8) Morinishi, K., An Upwind Gridless Type Solver for Compressible Flows, Transactions of the Japan Society of Mechanical Engineers, B 66 (2000), 3092-3099.

(9) Morinishi, K., A Gridless Type Solver - Generalized Finite Difference Method -, Computational Fluid Dynamics for the 21st Century, Notes on Numerical Fluid Mechanics, Springer, 78 (2001), 43-58.

(10) Abe, T. and Oguchi, H., A Hierarchy Kinetic Model and Its Applications, Rarefied Gas Dynamics, Progress in Astronautics and Aeronautics, AIAA, 58 (1977), 781-793.

(11) Morinishi, K., Parallel Computation of Gridless Type Solver for Unsteady Flow Problems, Parallel Computational Fluid Dynamics, Elsevier, (2002) 275-284.

(12) Morinishi, K., Parallel Computation of Higher Order Gridless Type Solver, Parallel Computational Fluid Dynamics, Elsevier, (2003) 427-434.

(13) Jameson, A. and Yoon, S., Lower-Upper Implicit Schemes with Multiple Grids for the Euler Equations, AIAA Journal, 25 (1987), 929-935.

(14) Maslach, G.J. and Schaaf, S.A., Cylinder Drag in the Transition from Continuum to Free-Molecule Flow, Physics of Fluids, 6 (1963), 315-321. 